\title{
Ovarian preantral follicles are responsive to FSH as early as the primary stage of development
}

\author{
Juliana I Candelaria', Maria B Rabaglino² and Anna C Denicol1 \\ 1Department of Animal Science, University of California Davis, Davis, California, USA \\ 2Department of Applied Mathematics and Computer Science, Technical University of Denmark, Kongens Lyngby, Denmark
}

Correspondence should be addressed to A C Denicol: acdenicol@ucdavis.edu

\begin{abstract}
Follicle-stimulating hormone (FSH) is required for ovarian antral folliculogenesis and steroidogenesis, and there is increasing evidence that it may play critical roles in preantral follicle development. We hypothesized that preantral follicles begin responding to FSH as early as the primary stage of development. Our objectives were to establish whether the FSH receptor (FSHR) was expressed in bovine preantral follicles and to determine the effects of FSH in these follicles and the surrounding ovarian tissue. Preantral follicles were isolated from bovine ovaries and subjected to immunolocalization of FSHR. Ovarian cortical strips were cultured with FSH or vehicle for 2 or 4 days and subjected to RNA sequencing, hematoxylin/eosin staining and immunostaining for p42/44 MAPK. Finally, cortical strips were cultured for 4 days with FSH before Western blot analysis of total and phosphorylated p42/44 MAPK and total aromatase. We found greater FSHR labeling intensity per cell in preantral follicles at the primary stage compared to other stages $(P<0.05)$. FSH upregulated genes involved in energy metabolism and MAPK signaling and downregulated genes related to phagosome and allograft rejection in the ovarian cortex. Preantral follicles cultured in situ with FSH had greater expression of total p42/44 MAPK $(P<0.05)$, but no difference was detected in whole tissue Western blot for phosphorylated p42/44 MAPK or aromatase. We conclude that the FSHR is expressed in preantral follicles as early as the primary stage of development, and that FSH upregulates cell metabolism and activates MAPK signaling pathways in preantral follicles.
\end{abstract} Key Words

\section{Introduction}

Ovarian antral follicles require gonadotropin stimulation for development and ovulation whereas preantral follicles seem capable of development in the absence of folliclestimulating hormone (FSH) and luteinizing hormone (LH), suggesting that gonadotropins are not required for preantral follicular development (Dufour et al. 1979, Kumar et al. 1997, Balla et al. 2003, Pakarainen et al. 2005). Although folliculogenesis arrest occurs at the late preantral/early antral stages in hypophysectomized mice and ewes, a reduction in the number of small preantral follicles has also been observed, indicating that although not required, FSH may have a physiological role in preantral folliculogenesis (Dufour et al. 1979, Wang \& Greenwald 1993). Additional evidence of a role for FSH in preantral follicle development comes from the findings of FSHR mRNA and protein in follicles as early as the primary stage in humans, mice, sheep, pigs, and rabbits (Tisdall et al. 1995, Rajapaksha et al. 1996, Oktay et al. 1997, 
Durlej et al. 2011, Lan et al. 2014). Furthermore, in vitro studies demonstrate that presence of FSH improves longterm survival of preantral follicles in culture and promotes development of healthy oocytes (Roy \& Treacy 1993, Cortvrindt et al. 1997, Wright et al. 1999, Mao et al. 2002, Adriaens et al. 2004, Hardy et al. 2017).

The canonical pathway stimulated by FSH in antral follicles results in activation of protein kinase A (PKA) and other regulatory proteins (Hunzicker-Dunn etal. 2012). The PKA pathway has multiple downstream targets including proteins of the MAPK family which directly and indirectly drive granulosa cell proliferation and differentiation (Shiota et al. 2003, Wayne et al. 2007, Puri et al. 2016), and ovulation of antral follicles (Schuermann et al. 2018). More specifically, phosphorylated p42/44 MAPK has been shown to contribute to the expression of genes required for development of the preovulatory follicle, such as Cyp19a1, Lhcgr, Inha, and Inhb (Kwintkiewicz et al. 2007).

Despite the presence of FSHR in preantral follicles and the knowledge that FSH improves preantral follicle development in vitro, there have been no studies to elucidate the global changes elicited by FSH or whether all preantral follicle stages can respond to it. Likewise, studies showing MAPK pathways as targets of FSH are limited to antral follicles and cultured granulosa cells (Kwintkiewicz et al. 2007, Schuermann et al. 2018). In this study, we tested the hypothesis that growing preantral follicles are responsive to FSH starting at the primary stage of development, the very first stage following activation of the quiescent primordial follicle. Our objectives were to (1) detect expression of the FSH receptor (FSHR) in growing bovine preantral follicles; (2) evaluate the global transcriptomic changes in the ovary cortex in response to FSH stimulation; and (3) examine whether FSH induced changes in p42/44 MAPK and CYP19A1 (aromatase) protein expression in preantral follicle granulosa cells.

\section{Materials and methods}

All materials were purchased from Fisher Scientific unless otherwise noted.

\section{Preantral follicle isolation}

Bovine ovaries were sourced from a local abattoir and transported in warm saline. Preantral follicles were mechanically isolated by homogenization followed by sequential filtration. Ovaries were homogenized (Omni Macro Homogenizer, Omni International, Kennesaw,
GA, USA) for $1 \mathrm{~min}$ at $3500 \mathrm{~g}$ and the homogenate was filtered through a cloth. The resulting filtrate was strained through a $200 \mu \mathrm{m}$ followed by a $40 \mu \mathrm{m}$ cell strainer. Material retained in the $40 \mu \mathrm{m}$ strainer was rinsed out with wash medium (TCM 199 containing $3 \mathrm{mg} / \mathrm{mL}$ BSA, $25 \mathrm{mM}$ Hepes, $1 \mathrm{mM}$ sodium pyruvate, $100 \mathrm{nM}$ non-essential amino acids, $100 \mathrm{IU}$ penicillin, $100 \mu \mathrm{g} / \mathrm{mL}$ streptomycin) and preantral follicles were searched under a stereomicroscope. Follicles were selected based on morphology (absence of antrum, visible oocyte, and intact basement membrane) and placed in drops of wash medium. Next, follicles were incubated in $0.02 \%(\mathrm{v} / \mathrm{v})$ trypan blue in PBS for 1 min to assess viability. After washing in PBS containing $0.1 \%(\mathrm{w} / \mathrm{v})$ polyvinylpyrrolidone (PVP), follicles that remained unstained were considered viable and used for subsequent experiments. A total of 187 preantral follicles (49 primary, 78 early secondary, 60 secondary classified according to Candelaria \& Denicol 2020) were obtained in 18 collection days.

\section{Immunolocalization of FSHR in preantral follicles and cumulus-oocyte complexes (COCs)}

Fresh preantral follicles and COCs were placed in drops of $4 \%(\mathrm{v} / \mathrm{v})$ paraformaldehyde (PFA) for $15 \mathrm{~min}$, washed in wash buffer (PBS containing $0.1 \%(\mathrm{v} / \mathrm{v})$ Tween 20 and $0.1 \%(\mathrm{w} / \mathrm{v}) \mathrm{BSA}$ ) and permeabilized (PBS containing 0.3\% $(\mathrm{v} / \mathrm{v})$ Triton $\mathrm{x}-100$ and $0.1 \%(\mathrm{w} / \mathrm{v}) \mathrm{BSA}$ ) for $10 \mathrm{~min}$ at room temperature (RT). Next, follicles were placed in $3 \%(\mathrm{v} / \mathrm{v})$ avidin and 3\% (v/v) biotin blocking solutions (SP2001, Vector Laboratories) for 15 min each at RT. Follicles were washed and incubated in blocking solution (5\% (v/v) normal donkey serum in PBS) for $1 \mathrm{~h}$ at RT, followed by overnight incubation in $2 \mu \mathrm{g} / \mathrm{mL}$ rabbit anti-mouse FSH receptor antibody (FSHR, ab113421, Abcam) at $4^{\circ} \mathrm{C}$. Bovine COCs were used as a positive control to validate specificity of antibody binding to the FSHR. Follicles were subsequently incubated with $3 \mu \mathrm{g} / \mathrm{mL}$ biotinylated donkey-anti-rabbit IgG secondary antibody (711-065-152, Jackson Laboratories) for $1 \mathrm{~h}$ at RT. Finally, follicles were placed in drops of $5 \mu \mathrm{g} / \mathrm{mL}$ avidin-conjugated FITC for $1 \mathrm{~h}$ at RT in the dark followed by $10 \mathrm{~min}$ with $1 \mu \mathrm{g} / \mathrm{mL}$ Hoechst 33342 to label DNA. Follicles were imaged with an inverted epifluorescence microscope (Revolve, Echo Labs, San Diego, CA, USA) under FITC and DAPI channels using fixed exposure time and settings. Every replicate included negative control follicles by omitting the primary antibody and replacing it with rabbit isotype IgG (Supplementary Fig. 1, see section on supplementary materials given at the end of this article). Expression of 
FSHR was quantified in the FITC channel in arbitrary fluorescence units by signal intensity using ImageJ software (NIH). Two readings were taken for each follicle and averaged. The average intensity reading from the negative control follicles for each replicate was subtracted from the average intensity for each positive follicle to control for background fluorescence. Cell number was determined for each individual follicle by counting cell nuclei. The final calculated FSHR signal intensity was then divided by the number of cells of each individual follicle to generate FSH staining intensity per cell.

\section{Immunolocalization of FSHR in the ovarian cortex}

Ovarian cortex was fixed in 4\% PFA overnight and placed in $30 \%(\mathrm{w} / \mathrm{v})$ sucrose until the sample sunk to the bottom of the jar. Next, cortex tissue was embedded in OCT compound, frozen at $-80^{\circ} \mathrm{C}$, sectioned in $10-\mu \mathrm{m}$ slices and placed on positively charged slides. Slides containing sections were washed in TBS to remove OCT before antigen retrieval. Slides were incubated with citric acid-based antigen-retrieval solution ( $\mathrm{pH} \mathrm{6)}$ (H-3300, Vector Laboratories) and placed in a steamer at $200^{\circ} \mathrm{C}$ for $10 \mathrm{~min}$. After cooling, slides were washed (twice for 5 min) and blocked with 3\% biotin and avidin solution and with blocking solution (10\% donkey serum, 1\% BSA, $0.3 \mathrm{mM}$ glycine). Sections were incubated with $10 \mu \mathrm{g} / \mathrm{mL}$ of anti-FSHR antibody overnight in a humidified chamber at $4^{\circ} \mathrm{C}$ or with blocking solution only or a rabbit isotype IgG (negative controls). After washing (twice for 5 min), donkey-anti-rabbit biotinylated secondary antibody was added at $3 \mathrm{\mu g} / \mathrm{mL}$ for $1 \mathrm{~h}$, washed, and followed by incubation of $5 \mu \mathrm{g} / \mathrm{mL}$ avidin-conjugated FITC for $1 \mathrm{~h}$ at RT in the dark and 10-min incubation with $1 \mu \mathrm{g} / \mathrm{mL}$ Hoechst 33342. After mounting, slides were imaged to assess labeling of follicles.

\section{Ovarian cortical strip culture}

Ovarian cortex was cut into strips of $5 \times 10 \times 1 \mathrm{~mm}$ using a sterile scalpel blade and rinsed in wash medium. Before culture, cortical strips were carefully examined under a stereomicroscope for removal of visible antral follicles and luteal tissue. In experiment 1, cortical strips were washed in PBS and randomly assigned to be flash frozen in liquid nitrogen and immediately stored at $-80^{\circ} \mathrm{C}$ until RNA isolation, or fixed in 4\% PFA overnight (day 0 control), or cultured for 2 or 4 days in cortical strip medium (MEM-alpha glutamax containing $3 \mathrm{mg} / \mathrm{mL}$ BSA, $10 \mathrm{mg} / \mathrm{L}$ insulin, $5.5 \mathrm{mg} / \mathrm{L}$ transferrin, $6.7 \mu \mathrm{g} / \mathrm{L}$ selenious acid, $100 \mu \mathrm{g} / \mathrm{mL}$ penicillin, $100 \mathrm{IU}$ streptomycin, $100 \mathrm{nM}$ non-essential amino acids, $50 \mu \mathrm{g} / \mathrm{mL}$ ascorbic acid) supplemented with $100 \mathrm{ng} / \mathrm{mL}$ of human recombinant FSH (hrFSH; RayBiotech, Peachtree Corners, GA, USA) or the equivalent volume of sterile MilliQ water (vehicle control). After 4 days, strips were harvested and either fixed in 4\% PFA for hematoxylin and eosin (H\&E) or immunostaining following cryosectioning, or flash frozen. In experiment 2, cortical strips were processed as previously described and cultured for 4 days with $100 \mathrm{ng} / \mathrm{mL} \mathrm{hrFSH}$ or vehicle. At the end of culture, cortical strips were flash frozen and immediately stored at $-80^{\circ} \mathrm{C}$ until processed for Western blotting. In both experiments, cortical strips were cultured in well insert membranes inside six-well plates containing $2 \mathrm{~mL}$ of culture medium in a humidified chamber at $38.5^{\circ} \mathrm{C}$ and $5 \% \mathrm{CO}_{2}$ in air. Medium was completely changed every day. Each experiment was performed in three replicates.

\section{Immunolocalization of p42/44 MAPK}

After 4 days of culture, cortical strips were processed for cryosectioning as previously described. Tissue sections were incubated with $0.5 \mu \mathrm{g} / \mathrm{mL}$ of rabbit polyclonal antibody against p44/42 MAPK (4695, Cell Signaling Technology) or a rabbit isotype IgG overnight in a humidified chamber at $4^{\circ} \mathrm{C}$. After washing, $1 \mu \mathrm{g} / \mathrm{mL}$ FITCconjugated donkey anti-rabbit secondary antibody was added for $1 \mathrm{~h}$ at RT, followed by 10 min incubation with $1 \mu \mathrm{g} / \mathrm{mL}$ Hoechst 33342. Slides were imaged and preantral follicles showing the oocyte were included for analysis. Intensity of the fluorescence signal in the FITC channel was measured for each follicle using ImageJ software.

\section{Western blot}

Ovarian cortex was flash frozen and homogenized over liquid nitrogen. For extraction of membrane-bound FSHR, homogenate was placed in a tube containing membrane extraction buffer $(25 \mathrm{mM}$ Tris, $1 \mathrm{mM}$ EDTA, $0.1 \% \beta$-mercaptoethanol, $0.25 \mathrm{M}$ sucrose, $\mathrm{pH} 7.4$, protease inhibitor (Roche)) and chilled on ice for $15 \mathrm{~min}$. The solution was centrifuged at $11,000 \boldsymbol{g}$ for $20 \mathrm{~min}$ at $4^{\circ} \mathrm{C}$. The supernatant was subjected to ultracentrifugation at $100,000 \mathrm{~g}$ for $1 \mathrm{~h}$ at $4^{\circ} \mathrm{C}$. The sample was frozen/thawed to dislodge the membrane protein pellet and reconstituted with $25 \mathrm{mM}$ Tris buffer. Protein concentration was quantified with a Bradford assay. For extraction of cytoplasmic p42/44 MAPK and aromatase, homogenized tissue was incubated in RIPA buffer for $2 \mathrm{~h}$ at $4^{\circ} \mathrm{C}$ and 
centrifuged for $3 \mathrm{~min}$ at $300 \mathrm{~g}$. Protein was denatured and reduced with Laemmli buffer (Bio-Rad) with 1M of DTT or $10 \% \beta$-mercaptoethanol and the solution was boiled for 5 min. Thirty micrograms of protein and ladder were loaded into each lane of a $10 \%$ polyacrylamide gel (Bio-Rad) for electrophoresis. After the protein was transferred to a PVDF membrane, the membrane was blocked with 5\% dry milk and $0.1 \%$ tween for $1 \mathrm{~h}$ at RT. The membranes were incubated with FSHR $(1 \mu \mathrm{g} / \mathrm{mL}), \mathrm{p} 44 / 42$ MAPK $(0.084 \mu \mathrm{g} / \mathrm{mL})$, phosphorylated p42/44 MAPK $(0.2 \mu \mathrm{g} / \mathrm{mL}$, 9101, Cell Signaling Technology), aromatase $(0.5 \mu \mathrm{g} / \mathrm{mL}$; ab18995, Abcam), rabbit isotype control $(1 \mu \mathrm{g} / \mathrm{mL})$, and loading control histone 3 antibodies $(0.2 \mu \mathrm{g} / \mathrm{mL}$; ab1791, Abcam) overnight at $4^{\circ} \mathrm{C}$. Membranes were washed and incubated with HRP-conjugated donkey anti-rabbit secondary antibody (Jackson Laboratories) for $1 \mathrm{~h}$ at RT. After washing, colorimetric detection was performed using Ultra TMB solution. Densiometric quantification of bands was done using ImageJ software.

\section{RNA isolation and 3'-Tag RNA sequencing}

Cortical strips frozen at day 0 or after 2 and 4 days of culture were homogenized over liquid nitrogen. Total RNA was extracted using Trizol Plus RNA Purification Kit following manufacturer instructions. Genomic DNA was removed with an on-column procedure. Concentration and quality of RNA were assessed using Nanodrop and 2100 Bioanalyzer (Agilent Technologies) or Caliper LabChip GX Analyzer. RNA samples were submitted to the DNA Technologies and Expression Analysis Core at UC Davis. Gene expression profiling was carried out using a 3'-Tag-RNA-Seq protocol. Barcoded sequencing libraries were prepared using the QuantSeq FWD kit (Lexogen, Vienna, Austria) for multiplexed sequencing according to the recommendations of the manufacturer using UDI-adapter and UMI Second- Strand Synthesis modules (Lexogen). The fragment size distribution of the libraries was verified via micro-capillary gel electrophoresis on a LabChip GX system (PerkinElmer). The libraries were quantified by fluorometry on a Qubit fluorometer (Life Technologies) and pooled in equimolar ratios. Libraries were sequenced in one lane of the HiSeq 4000 sequencer (Illumina) with single-end 100 bp reads.

\section{Bioinformatic analysis}

The raw FASTQ files were quality-checked using FastQC (v. 0.11.2) (Leggett et al. 2013), and Trimmomatic software was employed for quality trimming and adapters clipping
(Bolger et al. 2014). The remaining reads were aligned to the bovine reference genome (Bos taurus UMD3.1) and the read counts estimated at gene level, performing these steps with the Rsubread package for the R software (Liao et al. 2013). As unsupervised analysis, a multidimensional scaling (MDS) plot was made to establish relatedness between samples and identify any outliers with the Glimma package (Su et al. 2017). The remaining steps were performed with the edgeR package (Robinson et al. 2010). First, low-expression genes were filtered out if there were less than 1 count per million mapped reads in at least three of the samples. Next, between-sample normalization was performed using Trimmed Mean of $\mathrm{M}$ (TMM) and a robust estimate of the negative binomial dispersion parameter was applied to each gene by using observation weights. Finally, a negative binomial generalized log-linear model was fit to read counts for each gene (McCarthy et al. 2012). A regression-based approach was used to find those genes with significant temporal expression changes and significant differences between FSH-treated and control groups. This analysis was performed with the maSigPro package (Nueda et al. 2014). Genes whose change in expression between groups was associated with FDR $<0.05$ were considered differentially expressed genes (DEG). DEG determined from the time-course analysis were clustered with Cluster 3.0 (de Hoon et al. 2004), according to their normalized expression level profile, using Spearman Rank Correlation as similarity metric and Centroid Linkage as the clustering method. Gene expressions were transformed and normalized to construct the hierarchical cluster and the heatmap for the expression levels. The clusters' tree and normalized values were plotted with Java Treeview (Saldanha 2004) in order to visualize the gene responses to FSH overtime. NetworkAnalyst software (www. networkanalyst.ca) (Xia et al. 2015) was used to identify relevant biological functions represented by differentially expressed genes. Biological processes, molecular functions, and cellular components with a $P$-value $<0.05$ were considered significantly enriched. Sequencing data have been deposited in NCBI's Gene Expression Omnibus (GEO) under accession number GSE147176.

\section{Statistical analysis}

Intensity of FSHR, p42/44 MAPK staining and Western blot data were analyzed by ANOVA using the PROC GLM procedure of SAS version 9.4. When appropriate, Tukey was used as a post hoc test. Models included the effects of treatment, stage of development (where applicable) 
and replicate. A linear regression analysis was performed using the stats and jtools packages for $\mathrm{R}$ to evaluate the relationship between cell number and intensity of FSHR staining within each developmental stage evaluated. Analysis of RNA sequencing data was performed using R software. For each cluster, the mean gene expression levels within day between treatments were compared by $t$-test using the SAS software. Expression levels of HDAC transcripts within day were also analyzed by $t$-test. No outliers were excluded from final data analyses. Comparisons associated with $P<0.05$ were considered significant.

\section{Results}

\section{Expression of FSHR in preantral follicles}

Binding specificity of the FSHR antibody was confirmed by immunolocalization and Western blot. We observed consistent signal for FSHR in cumulus cells but not in the oocyte in isolated COCs (Fig. 1A) and in cryosections of bovine ovary where we observed staining of granulosa cells of preantral and antral follicles (Fig. 1B and C). Western blot analysis of bovine ovary containing antral follicles resulted in a strong band of approximately $70 \mathrm{kDa}$ (Fig. 1D). While the full-length bovine FSHR is a $78 \mathrm{kDa}$ protein, a $70 \mathrm{kDa}$ FSHR has been identified and suggested to be an alternative-spliced protein whose transcript was shortened in the transmembrane and intracellular regions, but not the extracellular region which the antibody used in this study was raised against (O'Shaughnessy et al. 1996, Rajapaksha et al. 1996).

Preantral follicles were isolated via mechanical manipulation due to concerns that enzymatic digestion could potentially damage the membranebound FSHR. All preantral follicle stages examined expressed the FSHR (Fig. 2A). Some isolated follicles retained ovarian cells outside the basement membrane, and no signal was detected in those cells. The average number and range of cells were 57 (24-88) for primary, 104 (76-174) for early secondary and 182 (112-327) for secondary follicles. In a per follicle basis, there was no difference in the intensity of FSHR labeling between primary, early secondary and secondary stage follicles. When the intensity value was divided by the number of cells in each follicle, primary follicles had the highest expression of FSHR per cell, followed by early and secondary follicles ( $P<0.001$; Fig. $2 B$ ). Taking into consideration that immunolabeling per cell may not increase proportionally with the number of cells if there were no differences in receptor abundance, we subjected the data to linear regression analysis to verify our findings. The intensity of FSHR staining increased as the number of cells increased in primary and early secondary $(P<0.05)$, but not in secondary follicles ( $P=0.65$; Supplementary Fig. 2). Interestingly, when predicting the FSHR intensity in each stage while holding a constant number of cells (the overall cell number average of all stages), the predicted staining intensity was higher for primary follicles.
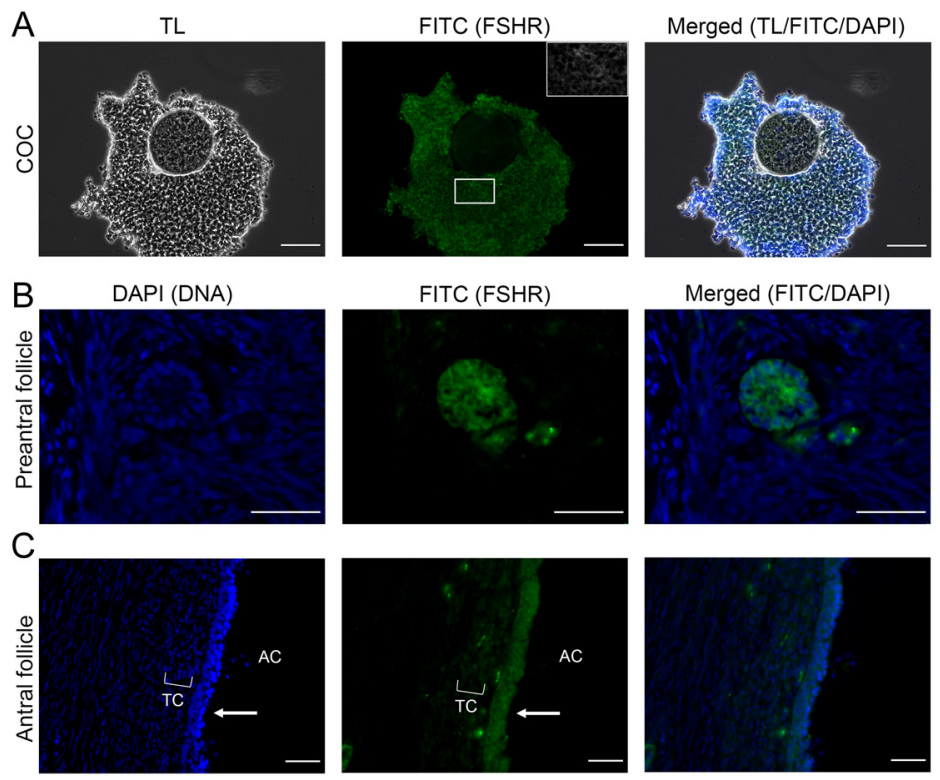

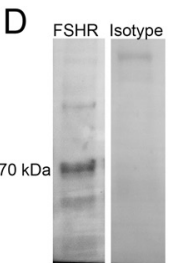
$\mathrm{H} 3 \mathrm{~A}$
$17 \mathrm{kDa}$

\section{Figure 1}

Validation of FSHR antibody specificity for the bovine receptor. (A) Cumulus-oocyte complex (COC) under transmitted light (TL), FITC channel showing FSHR expression, and merged image with DAPI labeling cell nuclei. Insert in FITC channel is a zoomed image of the region demarcated by the rectangle and shows peripheral localization of FSHR labeling. Scale bar $=100 \mu \mathrm{m}$. (B) Preantral follicle and (C) antral follicle cryosections labeled with FSHR. In C, arrow points to mural granulosa cells. TC, theca cells; AC, antral cavity. Scale bar $=50 \mu \mathrm{m}$. (D) Western blot of bovine ovarian tissue showing FSHR band around $70 \mathrm{kDa}$ and isotype control. Loading control antibody used was anti-histone 3A ( $\mathrm{H} 3 \mathrm{~A})$. A full colour version of this figure is available at https://doi.org/10.1530/JOE-20-0126. 
A
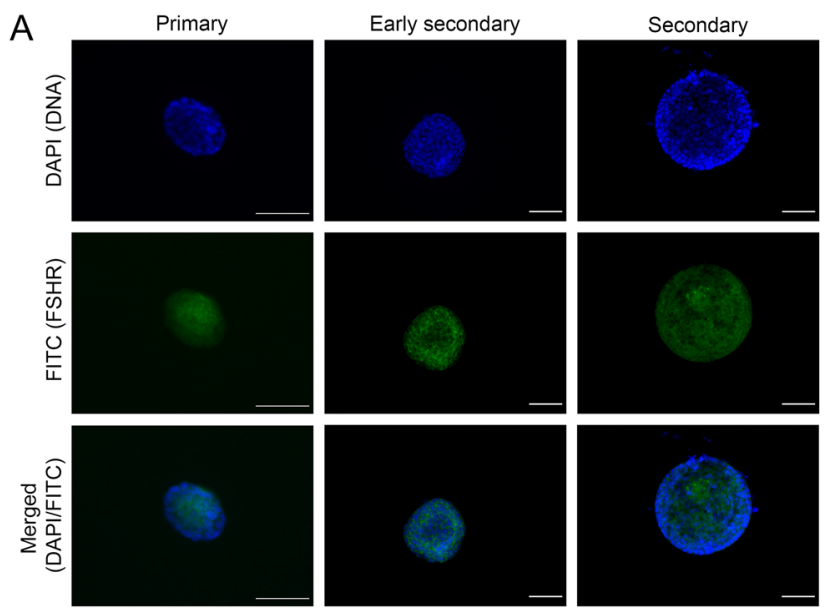

\section{B}

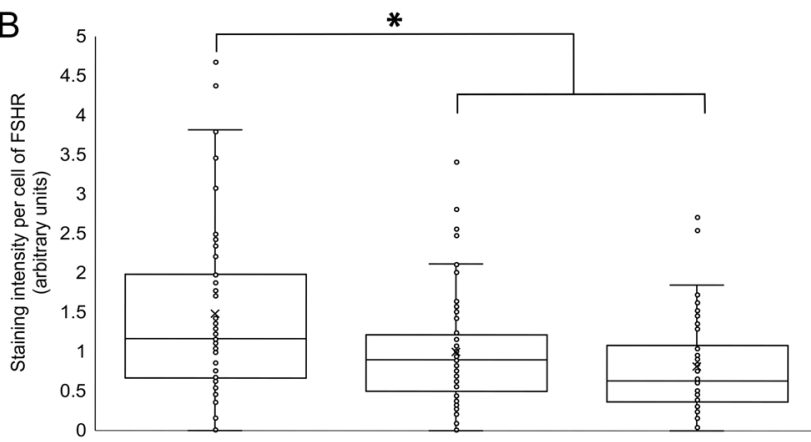

Figure 2

FSHR expression in growing bovine preantral follicles. (A) Primary, early secondary, and secondary follicles showing FSHR expression (FITC) and DNA labelling (DAPI). Scale bar $=50 \mu \mathrm{m}$. (B) Quantification of fluorescent signal intensity per cell for each follicular stage. Intensity for each follicle measured was divided by its number of granulosa cells to determine staining intensity per cell. Primary follicles showed higher signal intensity per cell $(* P<0.001)$ compared with early secondary and secondary follicles. A full colour version of this figure is available at https://doi.org/10.1530/JOE-20-0126.

\section{Ovarian follicle count and RNA sequencing of the ovarian cortex}

Upon finding ubiquitous expression of the FSHR in bovine preantral follicles, our next steps were to investigate whether FSH was altering the developmental dynamics of these follicles, and the global gene expression changes in the ovary enclosing preantral follicles in response to FSH.

Analysis of follicle count after H\&E staining showed a tendency for follicles exposed to FSH to be more advanced in development compared to vehicle control. The proportion of primordial follicles was $16.4 \pm 2.4$ and $3.3 \pm 2.4 \%$ in vehicle and FSH-treated, respectively $(P=0.06)$; proportion of primary follicles was $55.4 \pm 5.5$ and $65.8 \pm 5.5 \%$, and secondary follicles, $19.9 \pm 2$ and $24.4 \pm 2 \%$ in vehicle and FSH-treated, respectively $(P=\mathrm{NS})$.
The MDS plot of gene expression showed clear clustering of samples between FSH- and vehicle-treated at days 2 and 4 of culture (Fig. 3A). As time was the major driver of transcriptomic changes, samples at day 0 were excluded from the MDS in order to have a better discernment of the relationship between the other samples. All samples contained similar expression levels of germ cell markers such as ZP1, ZP2, ZP3, GDF9, $D D X 4$ and $D A Z L$, indicating that oocytes were present in the cultured ovarian strips and that their numbers were likely similar across samples. The gene B4GALT2, reported as a granulosa cell marker (Malcuit et al. 2009), was upregulated in FSH-treated samples at day 4. The follicular marker RAB23 (Malcuit et al. 2009) was expressed in all samples and not changed by FSH.

Time-course gene expression analysis identified 252 genes that changed over time in FSH-compared to the vehicle-treated ovary (Table 1 and Supplementary Table 1). Examining the cluster tree and heat map, we identified five gene clusters that responded similarly to FSH and that corresponded to the majority of the 252 DEGs (Fig. 3B, C, D, E and F). Mean expression profiles for each cluster revealed that clusters 1, 2 and 5 represented genes that responded positively to FSH either at day 2 or day 4 of culture (Fig. 3B, C and F). Cluster 3 represented genes that were downregulated by FSH (Fig. 3D). Genes grouped in cluster 4 were downregulated by FSH at day 2 and rescued at day 4, resulting in a subtle, although significant, upregulation compared to vehicle control. Clusters 1, 2 and 5, which contained genes upregulated by FSH, were combined for downstream analysis. The top three biological processes enriched by upregulated genes included glycolysis/gluconeogenesis, carbon metabolism, and biosynthesis of amino acids (Table 2); top three biological processes enriched by downregulated genes resulting from individual analysis of clusters 3 and 4 included phagosome, allograph rejection, and circadian rhythm (Table 3).

Finally, we searched for transcripts related to epigenetic changes that could be occurring in response to FSH. Nine members of the histone deacetylase family were expressed (HDAC1, HDAC2, HDAC3, HDAC5, HDAC6, HDAC7, HDAC8, HDAC10 and HDAC11), and three of them, HDAC6, HDAC8 and HDAC11 were downregulated by FSH (Fig. 4A, B and C).

\section{Protein expression of p42/44 MAPK and aromatase}

MAPK pathways have critical roles in cell proliferation and have been identified as targets of FSH signaling in 
A

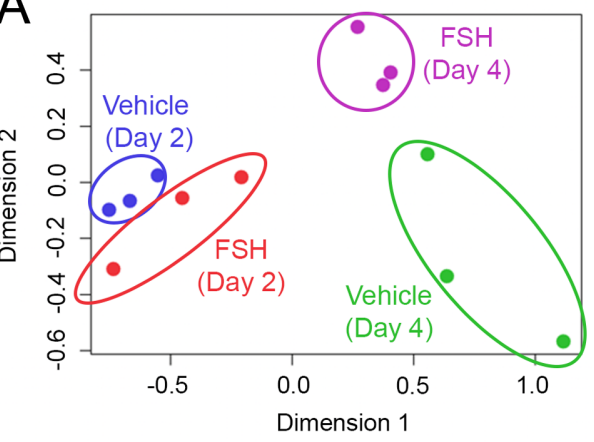

D
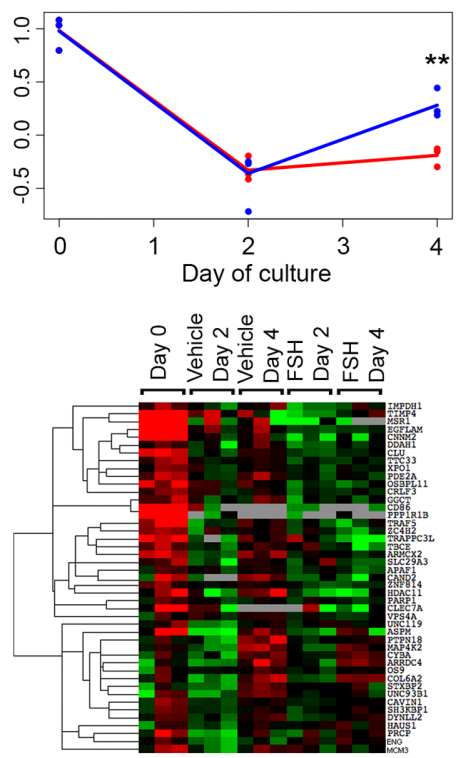

B
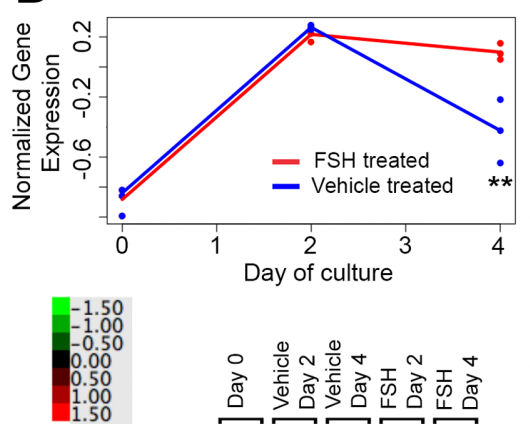

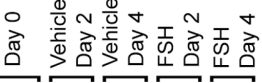

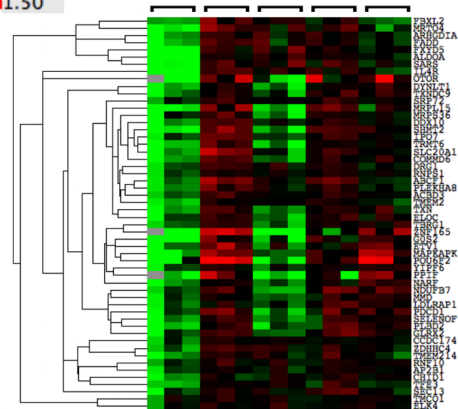

$E$
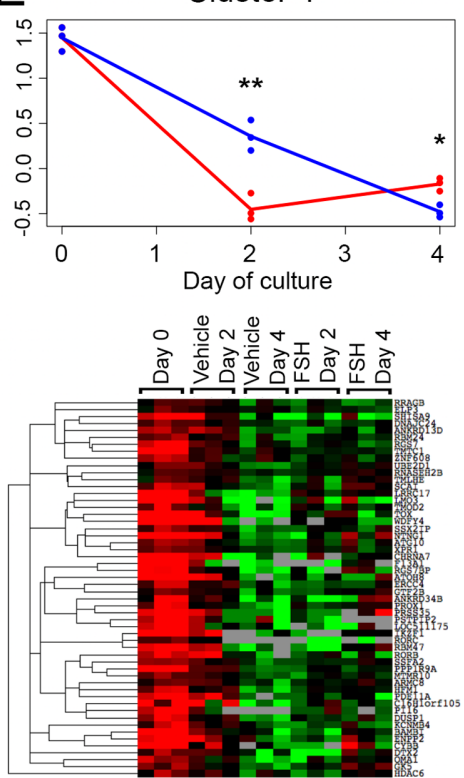

C
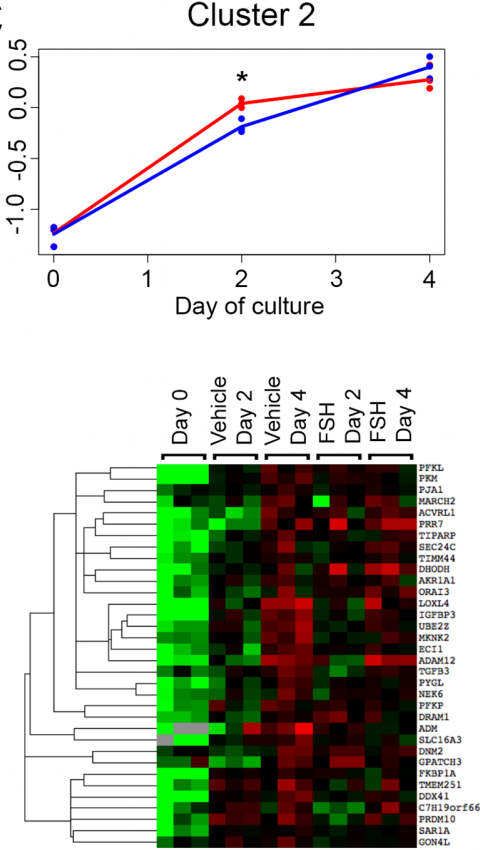

$\mathrm{F}$
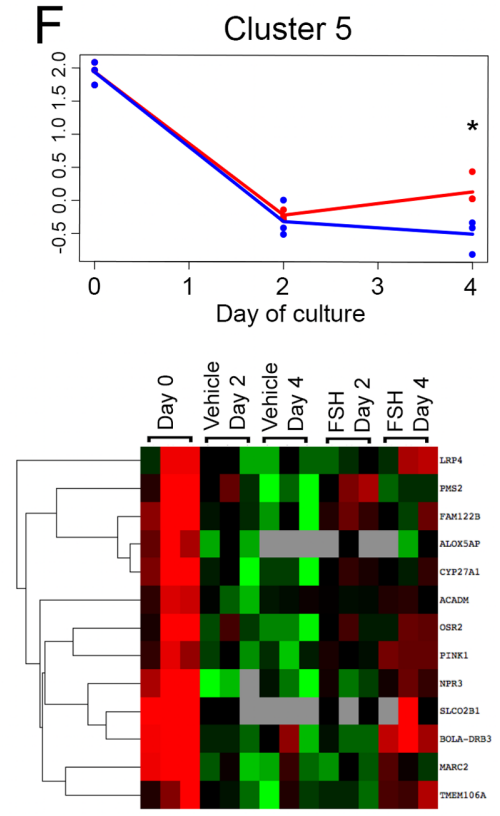

Figure 3

Transcriptomic profile of bovine ovarian cortical tissue after no treatment (day 0) or treatment with FSH or vehicle in the culture media for 2 and 4 days. (A) Multidimensional scaling (MDS) plot showing distinct clustering of samples according to day and treatment. (B, C, D, E and F) Clusters of genes found by time-course analysis to be differentially expressed between treatments over time are represented as a heatmap and line plot. Legend for heat map describes colors for highly upregulated genes (red) through highly downregulated genes (green). Asterisks denote significant differences between treatments within the same day: ${ }^{\star} P=0.01 ; * \star P<0.01$.

antral follicles. We used ovarian cortical strips cultured in parallel to the ones used for RNA sequencing to confirm our gene expression finding that MAPK signaling is a target of FSH in the ovary and to investigate whether FSH was stimulating MAPK in follicles, ovarian stromal cells, or both. Cortical strips harvested after 4 days of culture were immunolabeled with an antibody against total p42/44 MAPK. Agreeing with our previous observation, the majority of the preantral follicles found in the cortical tissue after 4 days of culture were in the primary stage 


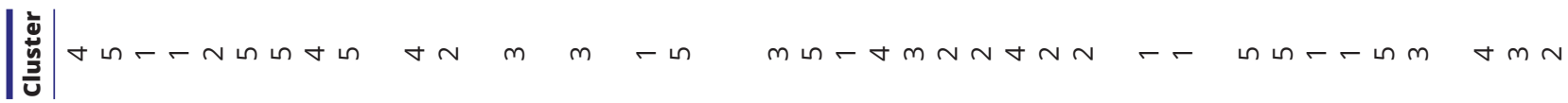
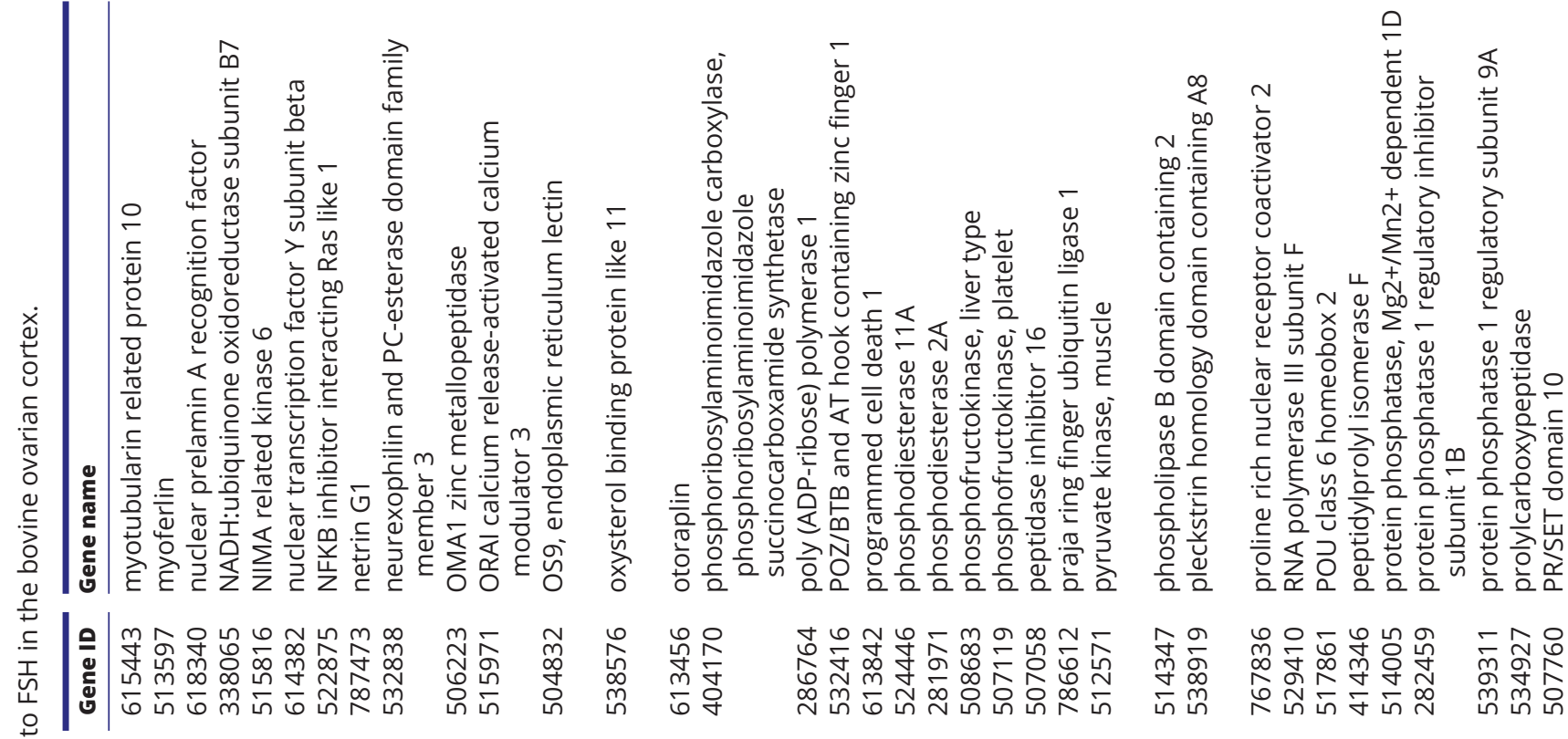

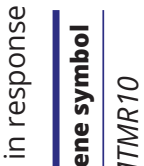

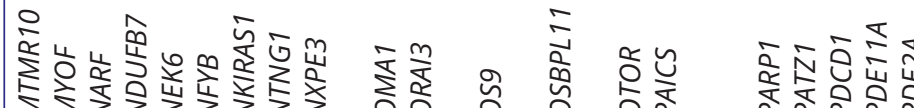

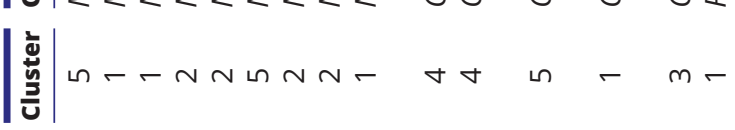

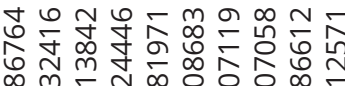

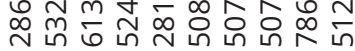

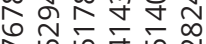

mิ

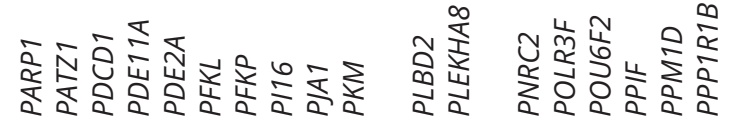

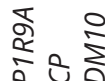

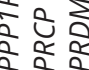

$\forall m m \operatorname{m} m \forall \forall \forall\llcorner\forall$

$\sim m$

$m \in \sigma \quad \forall n$

เก เก -
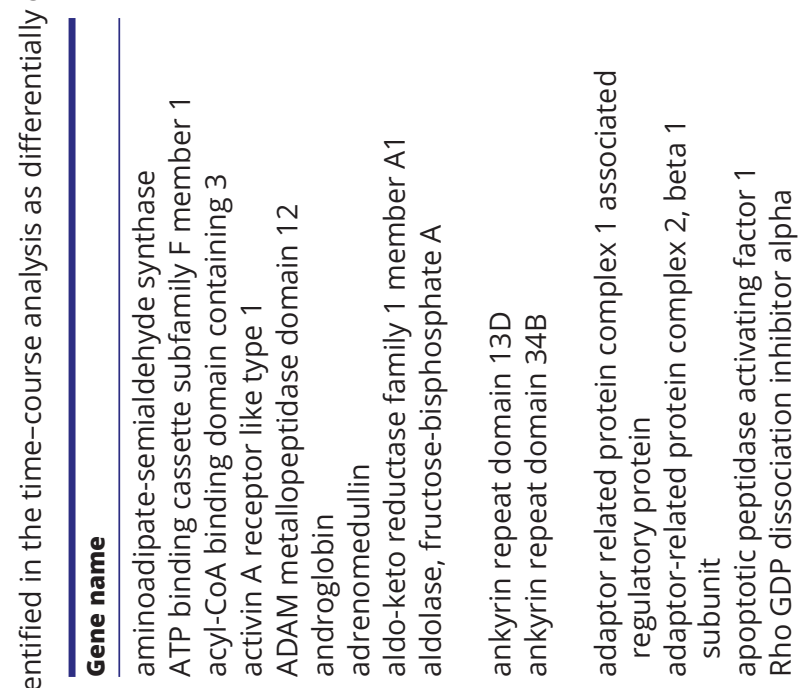

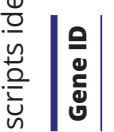
오요

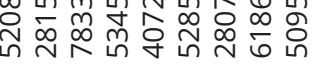

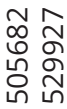

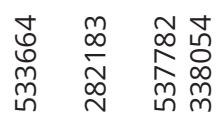

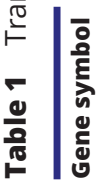

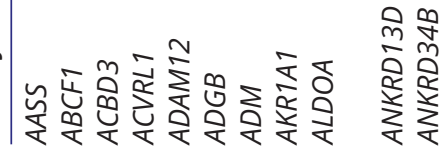

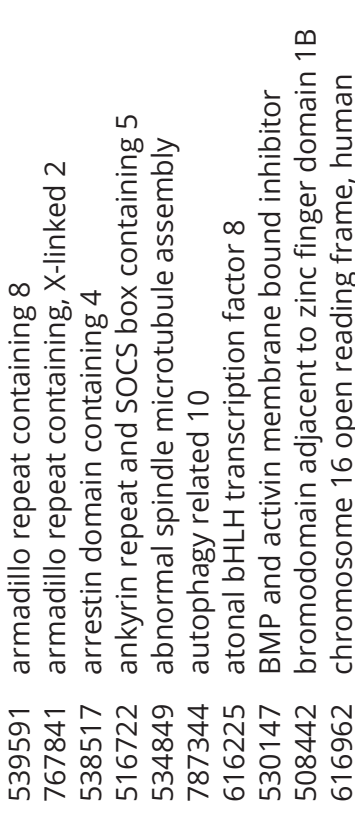

눈

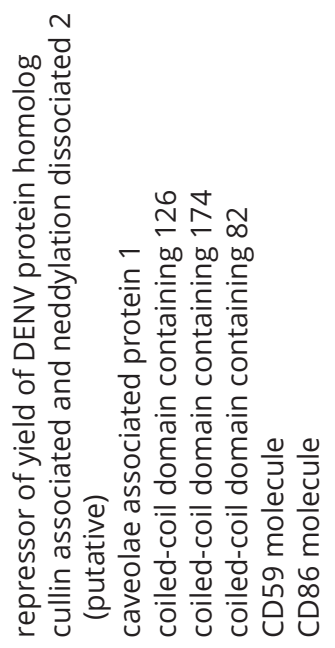

$\infty$

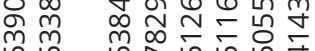

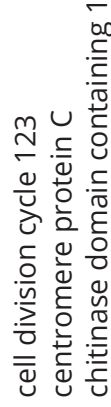

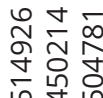



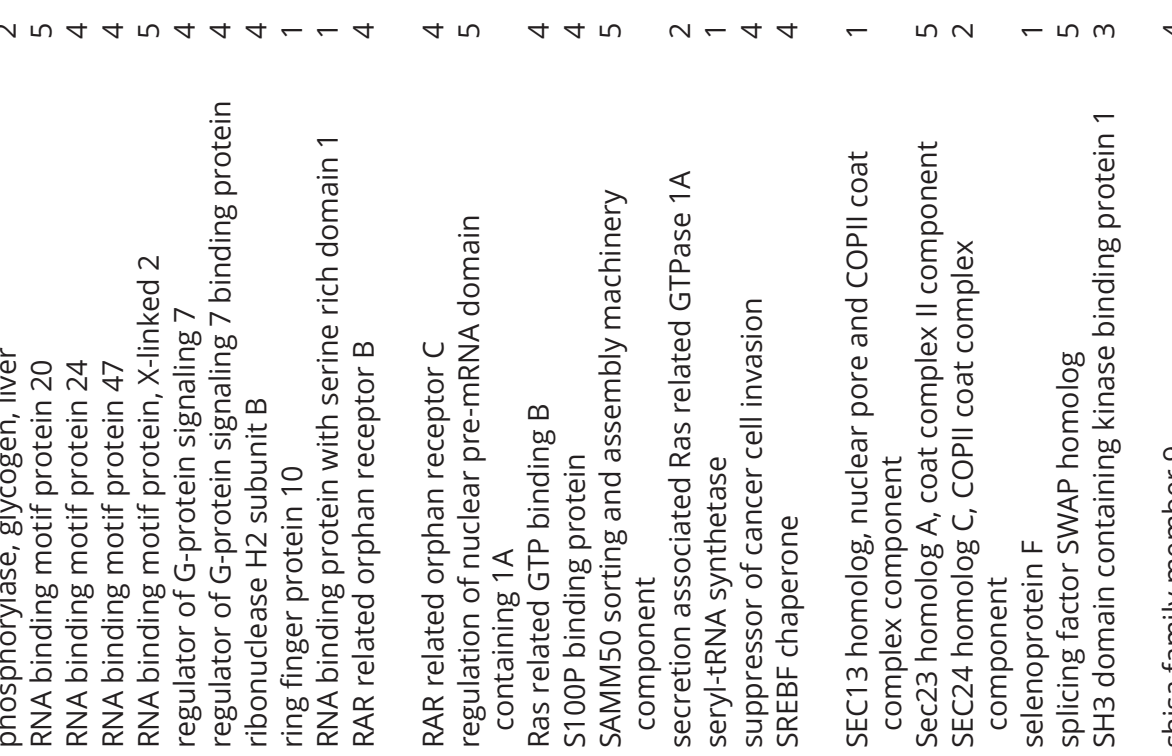

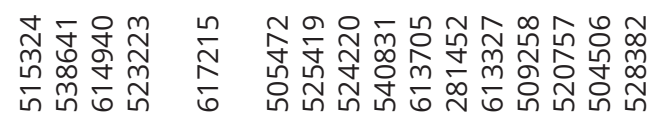

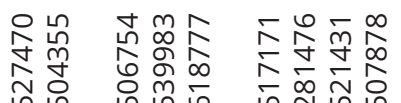

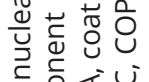

aí

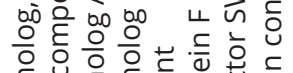

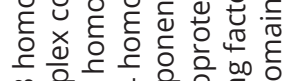

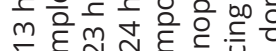

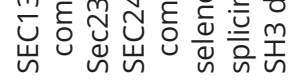

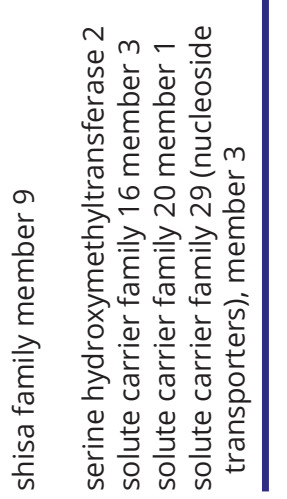

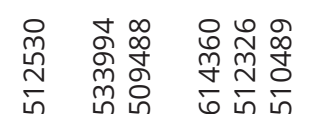

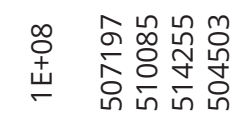

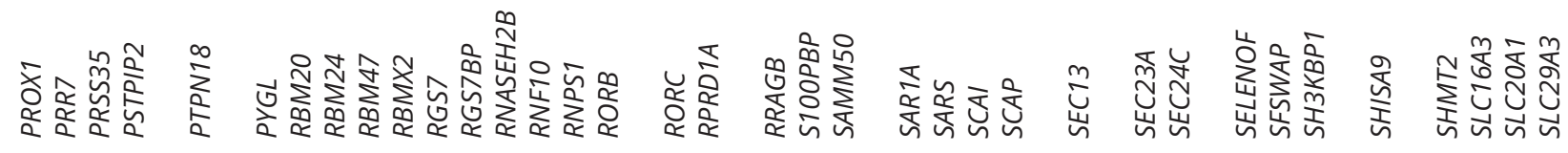

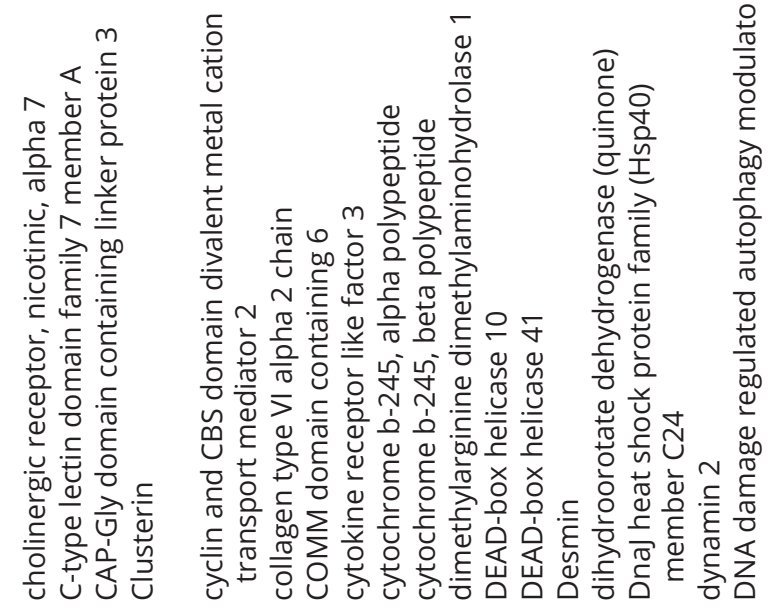

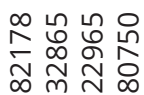

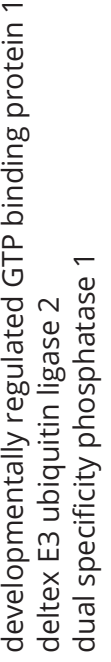

ธั \%ั

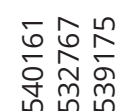

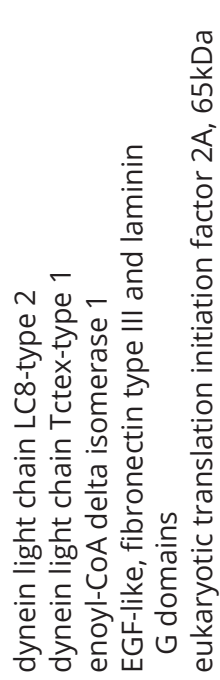

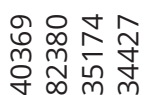

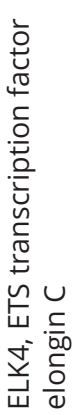

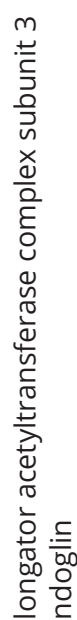

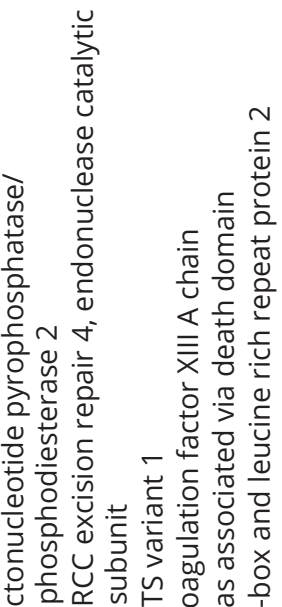

索

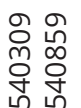

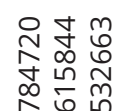

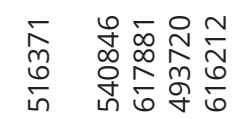

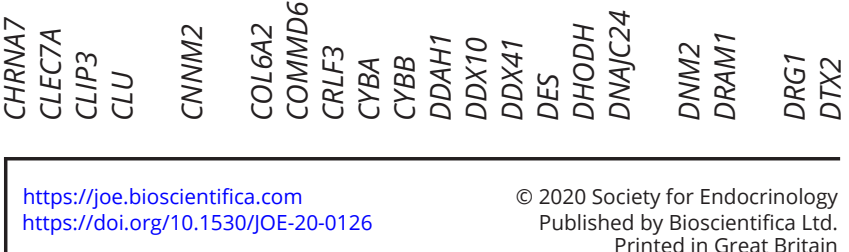

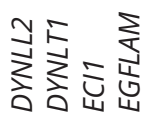

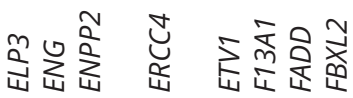




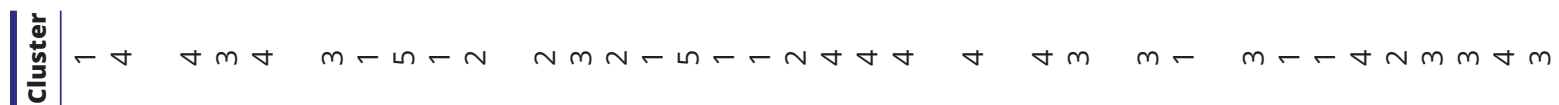

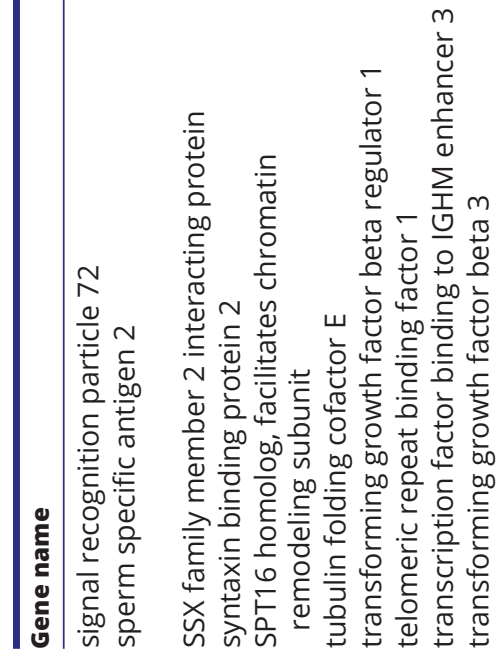

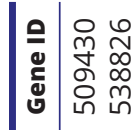

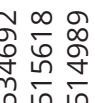

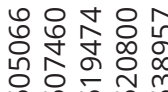

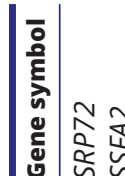

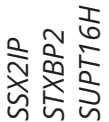

出䔎出员

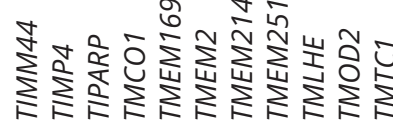

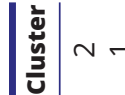

$-m$ in

$A-N \sim$

$\forall \sim m m+\forall \ln N+\leftarrow$

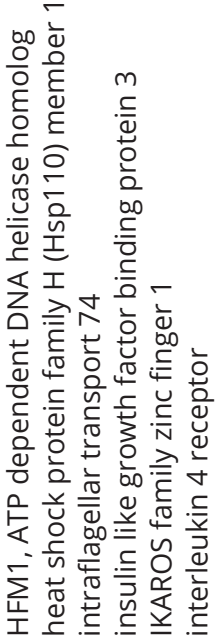

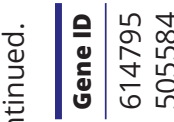

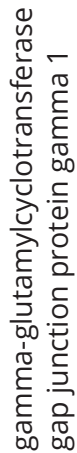

ํํำ

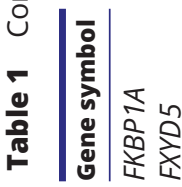

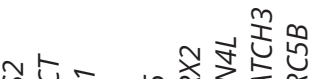

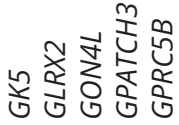

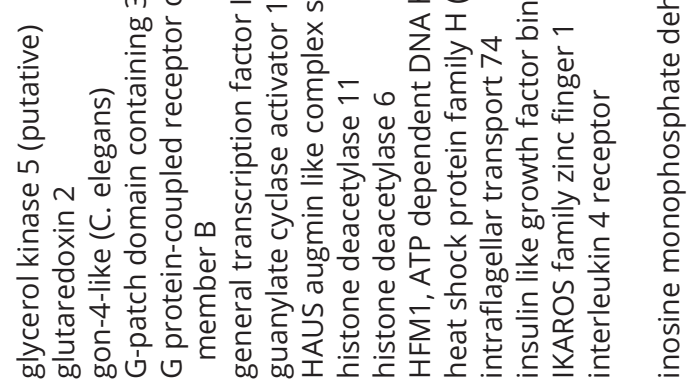

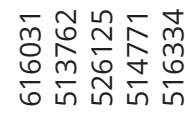

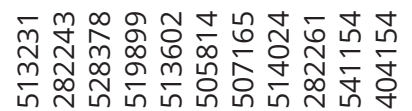

in 는 든ㅇํㅇํำ
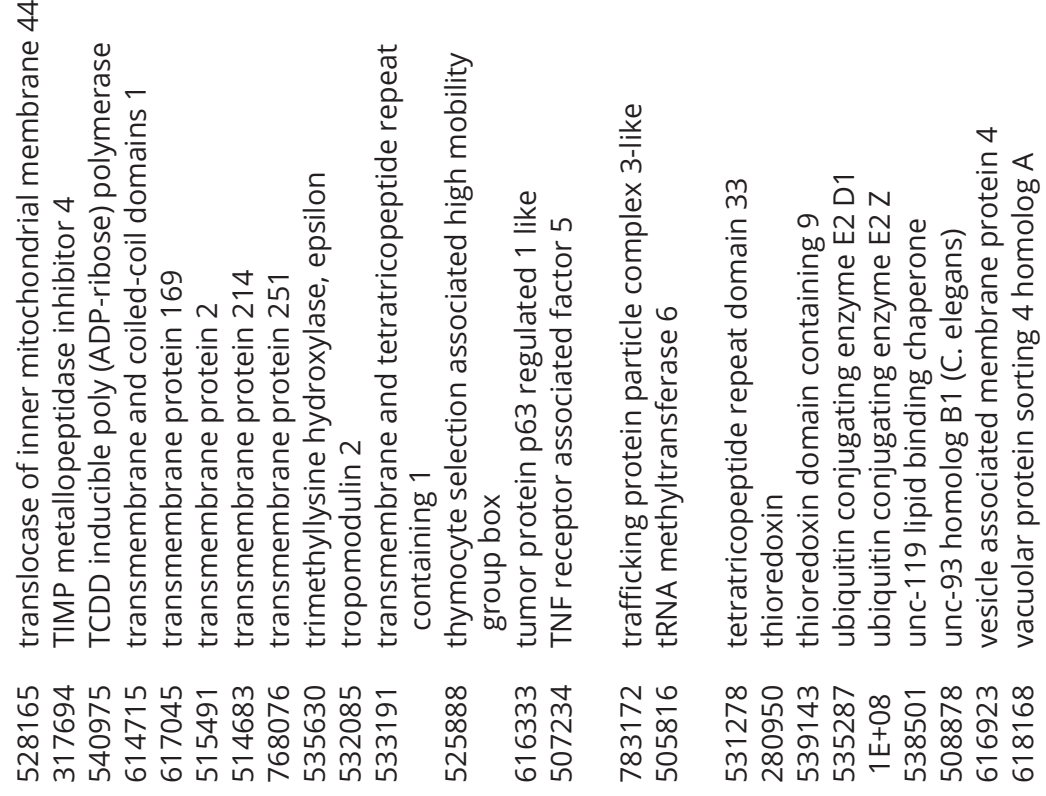

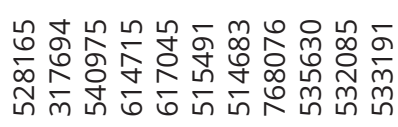

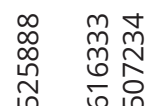

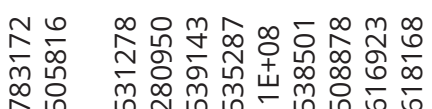

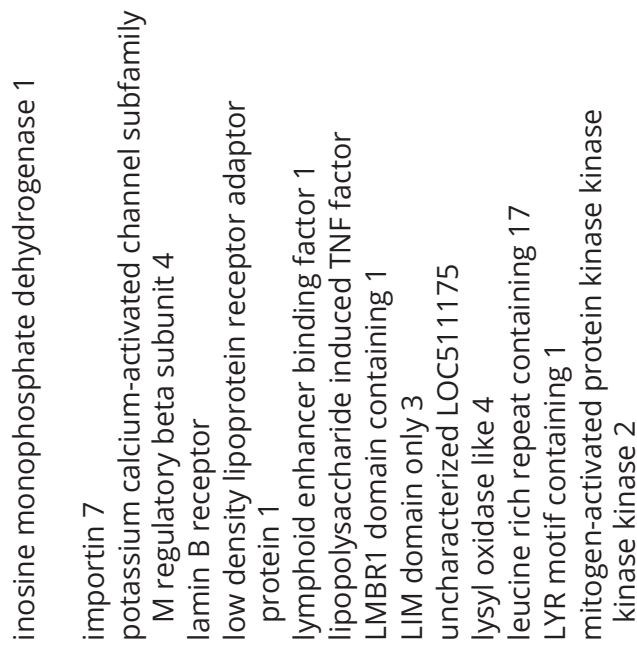

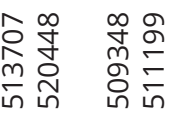

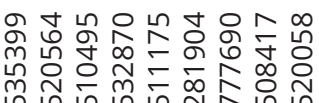

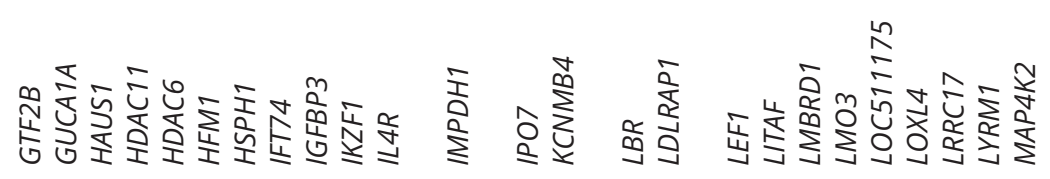


( $84 \%$ of the vehicle- and $62 \%$ of the FSH-treated follicles), with a small proportion of primordial ( $2 \%$ of vehicle and $4 \%$ of FSH), early secondary ( $2 \%$ of vehicle and $26 \%$ of FSH) and secondary stages (11\% of vehicle and $8 \%$ of FSH). Exposure to FSH increased expression of p42/44 MAPK in preantral follicles $(P<0.01$; Fig. $5 \mathrm{~A}$ and $\mathrm{B})$, and there was no difference in labeling intensity according to stage of development $(P=0.20)$. Labeling was localized to the granulosa cells within the follicles, and only faintly detected in parts of the ovarian stroma. Finally, we investigated whether FSH promoted phosphorylation of p42/44 MAPK using whole tissue Western blot analysis. Ovarian cortical strips were cultured for 4 days with FSH or vehicle, and expression of phospho- and total p42/44 MAPK were examined. We also evaluated the expression of aromatase, a known target of FSH signaling in antral follicles, but whose transcript abundance was not affected by FSH by RNA sequencing. There was clear protein expression of both total and phosphorylated p42/44 MAPK in the presence of FSH and a numerical, although not significant, decrease in expression in the vehicleexposed tissue ( $P=0.26$; Fig. $6 \mathrm{~A}$ and $\mathrm{B})$. The variability observed in MAPK expression may have resulted from variation in the number of follicles present within the fragments examined. Western blot analysis of aromatase expression revealed a clear band corresponding to the expected protein and no difference between treatments $(P=0.87$; Fig. $6 \mathrm{C}$ and $\mathrm{D})$, confirming the RNA sequencing results.

\section{Discussion}

Here we provide evidence that the FSH receptor is expressed in bovine growing preantral follicles as early as the primary stage of development. Moreover, we demonstrate for the first time that preantral follicles respond to FSH by upregulating specific cellular functions and pathways. Although expression of the FSHR in growing preantral follicles has been demonstrated in several species (Kristensen et al. 2015, Scarlet et al. 2016) including bovine (Marelli et al. 2018), we felt that it was critical to confirm expression of the receptor before moving on to evaluate possible effects of FSH in preantral follicles. Our main hypothesis that FSH plays a role in preantral follicle development comes from the accumulating evidence that preantral follicles benefit from FSH in vitro (Cortvrindt et al. 1997, Adriaens et al. 2004, Wu et al. 2007, Zhang et al. 2013, Aguiar et al. 2016, Bizarro-Silva et al. 2018) even though they may not have an absolute requirement 
Table 2 Biological processes enriched by the genes upregulated after exposure of the bovine ovarian cortex to FSH for 2 or 4 days.

\begin{tabular}{l}
\hline Biological process \\
\hline Glycolysis/gluconeogenesis \\
Carbon metabolism \\
Biosynthesis of amino acids \\
Central carbon metabolism in cancer \\
Pentose phosphate pathway \\
Fructose and mannose metabolism \\
Galactose metabolism \\
Fatty acid degradation \\
Parkinson's disease \\
Mitophagy - animal \\
Inflammatory bowel disease (IBD) \\
Protein processing in endoplasmic reticulum \\
Renal cell carcinoma \\
MAPK signaling pathway \\
PPAR signaling pathway
\end{tabular}

\begin{tabular}{l} 
Genes \\
\hline PFKL, PKM, AKR1A1, PFKP, ALDOA \\
PFKL, PKM, PFKP, ALDOA, SHMT2, ACADM \\
PFKL, PKM, PFKP, ALDOA, SHMT2 \\
PFKL, PKM, PFKP, SLC16A3 \\
ALDOA, PFKL, PFKP \\
ALDOA, PFKL, PFKP \\
PFKL, PFKP \\
ECI1, ACADM \\
PPIF, NDUFB7, PINK1 \\
TFE3, PINK1 \\
IL4R, TGFB3 \\
SEC13, SEC24C, SAR1A \\
TFE3, TGFB3 \\
MAPKAPK3, ELK4, MKNK2, TGFB3 \\
CYP27A1, ACADM
\end{tabular}

\begin{tabular}{l}
\hline P-value \\
\hline $9.71 \mathrm{E}-06$ \\
$1.04 \mathrm{E}-05$ \\
$1.86 \mathrm{E}-05$ \\
0.000163 \\
0.000269 \\
0.000483 \\
0.00875 \\
0.0157 \\
0.0309 \\
0.0365 \\
0.0386 \\
0.0393 \\
0.0417 \\
0.0436 \\
0.0494
\end{tabular}

Clusters 1, 2 and 5 were combined and the analysis performed using Network Analyst software.

on the hormone, as demonstrated by the apparent normal growth to the late secondary stage in FSHRknockout mice (Abel et al. 2000). The work of Adriaens et al. (2004) is of particular relevance in making the case for a role of FSH in preantral follicles by demonstrating that exposure to FSH during preantral development in vitro improved survival of mouse follicles, enhancing oocyte developmental competence and preimplantation embryonic development. Likewise, administration of exogenous FSH rescued preantral follicle development when juvenile rats were hypophysectomized or given a GnRH antagonist (McGee et al. 1997).

Upon confirmation of the presence of the receptor in all stages of growing follicles, we examined the global transcriptomic changes elicited by FSH in the preantral follicle-containing ovary to test the hypothesis that FSH would upregulate genes within pathways involved in cell proliferation and metabolism. Notably, the transcriptomic profile of the ovary in response to FSH included upregulation of genes related to MAPK pathways, a complex signaling system that utilizes substrates and targets depending on cell context, but is generally involved in regulation of cell proliferation, survival and differentiation (Zhang \& Liu 2002). FSH has been shown to stimulate MAPK pathways in antral follicle granulosa cells (Yu et al. 2005, Puri et al. 2016, Law et al. 2017). To our knowledge, this is the first report of MAPK stimulation by FSH in preantral follicles, shedding light into at least one specific role of FSH signaling in early follicle development. With the finding that p42/44 MAPK protein is increased in preantral follicles of all stages, we confirmed that FSH is indeed signaling in primary preantral follicles, likely mediated by the FSHR, which we found to be abundant in this follicular stage. It must be noted, however, that our RNA sequencing results include transcripts from cells found throughout the tissue, not solely follicular cells. We acknowledge the possibility that changes in gene expression observed here include indirect effects of FSH-stimulated granulosa cells in the surrounding

Table 3 Biological processes enriched by the genes downregulated in the bovine ovarian cortex after exposure to FSH for 2 or 4 days.

\begin{tabular}{|c|c|c|}
\hline & Genes & P-value \\
\hline \multicolumn{3}{|l|}{ Biological Process - Cluster 3} \\
\hline Phagosome & MSR1, CLEC7A, BoLA, CYBA & 0.001 \\
\hline Allograph rejection & $B o L A, C D 86$ & 0.009 \\
\hline Type-I diabetes mellitus & BoLA, CD86 & 0.01 \\
\hline Necroptosis & TRAF5, PARP1, VPS4A & 0.01 \\
\hline Viral carcinogenesis & BoLA, TRAF5, HDAC11 & 0.02 \\
\hline Endocytosis & BoLA, VPS4A, SH3KBP1 & 0.03 \\
\hline Protein digestion and absorption & COL6A2, PRCP & 0.04 \\
\hline \multicolumn{3}{|l|}{ Biological Process - Cluster 4} \\
\hline Circadian rhythm & $R O R C, R O R B$ & 0.003 \\
\hline Autophagy - animal & RRAGB, ATG10 & 0.04 \\
\hline
\end{tabular}

Clusters 3 and 4 represented genes that were downregulated by FSH after 2 days of culture; cluster 4 shows a recovery of expression at day 4 in response to FSH, while cluster 3 genes remain downregulated for the entire culture period. Analyses were performed using Network Analyst software. 

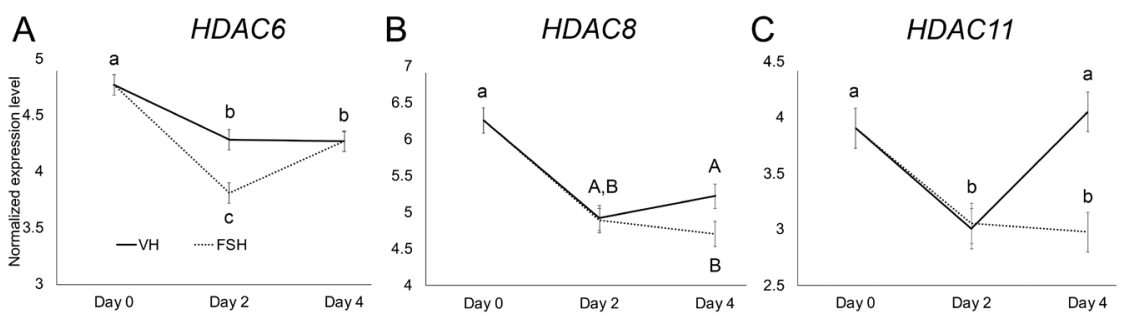

\section{Figure 4}

Expression of the histone deacetylases HDAC6 (A), HDAC8 (B), HDAC11 (C) in the ovarian cortex was affected by FSH. Overall, FSH had an inhibitory effect on expression of the three transcripts, with inhibition of HDAC6 being evident at day 2 and HDAC8 and HDAC11 at day 4 of culture. $\mathrm{a}, \mathrm{b}, \mathrm{c} P<0.01 ; \mathrm{A}, \mathrm{B} P=0.07$.

stromal cells. However, the demonstration of FSHR and p42/44 MAPK protein localization to the preantral follicles lead us to believe that the results we observed are indeed representative of changes within the follicles. Future transcriptomic studies should ideally examine isolated preantral follicles of specific stages in parallel with ovarian cortex for a better resolution of direct and indirect effects of FSH in this tissue.

Analysis of the ovarian cortex transcriptomic profile revealed decreased expression of the histone deacetylases
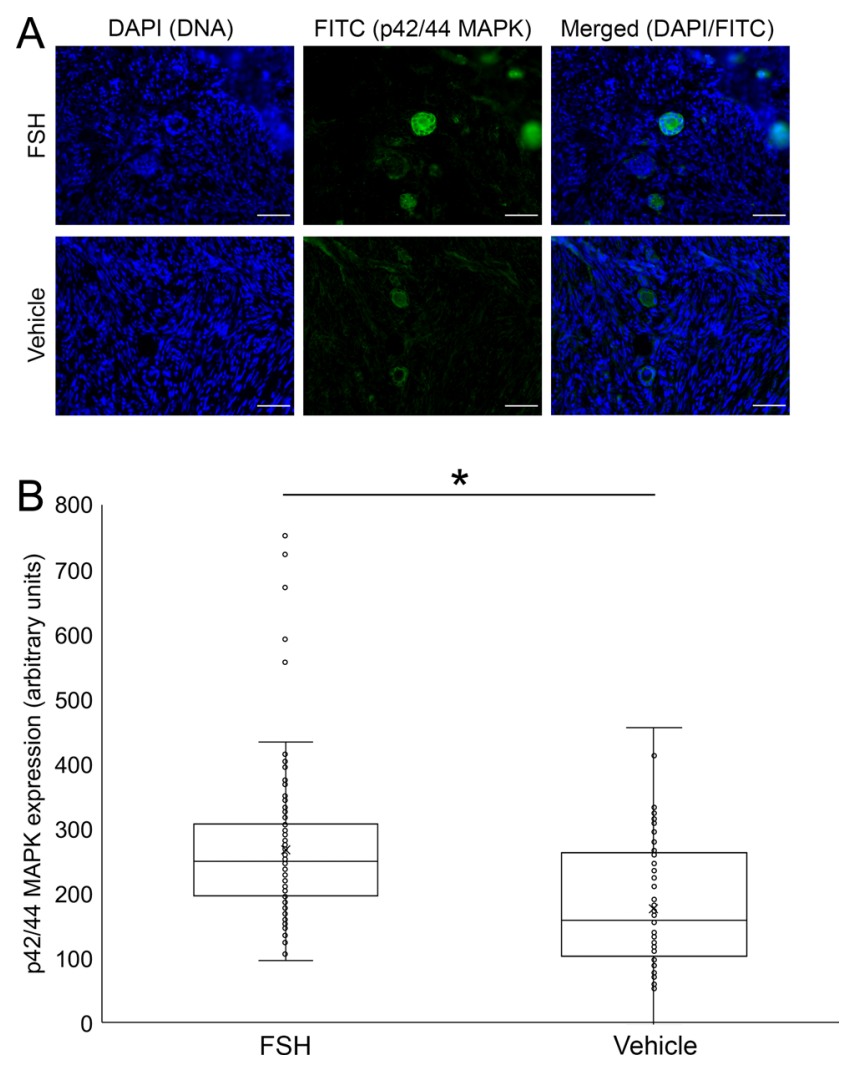

\section{Figure 5}

Expression of total p42/44 MAPK increases in preantral follicles exposed to FSH in situ (i.e. cultured within the ovarian cortex). (A) Expression of total p42/44 MAPK as assessed by fluorescence signal intensity, was stronger in preantral follicles exposed to FSH (100 ng/mL) compared to vehicle-treated tissue. Scale bar $=50 \mu \mathrm{m}$. (B) Quantification of staining intensity for total p42/44 MAPK in preantral follicles within tissue treated with $\mathrm{FSH}$ or vehicle ( $\left.{ }^{*} P<0.01\right)$. A full colour version of this figure is available at https://doi.org/10.1530/JOE-20-0126

(C) 2020 Society for Endocrinology Published by Bioscientifica Ltd. Printed in Great Britain

HDAC6, HDAC8 and HDAC11 in response to FSH at either day 2 or day 4 of culture. Histone acetylation is generally associated with a state of open, transcriptionally active chromatin, while deacetylated, or poorly acetylated histones generally indicate low transcriptional activity. HDACs associate with different proteins in co-repressor complexes to remove acetylation marks from histones, silencing expression of target genes (Verdin et al. 2003). Although the possible roles of HDACs as regulators of gene transcription in response to FSH during early folliculogenesis are largely unknown, evidence from adrenocortical cell culture experiments show that suppression of HDACs by chemical inhibitors suppresses steroidogenesis by targeting NR5A1 (steroidogenic factor 1, SF1) to ubiquitination (Chen et al. 2007). Moreover, exposure of bovine granulosa and theca cells to HDAC

A
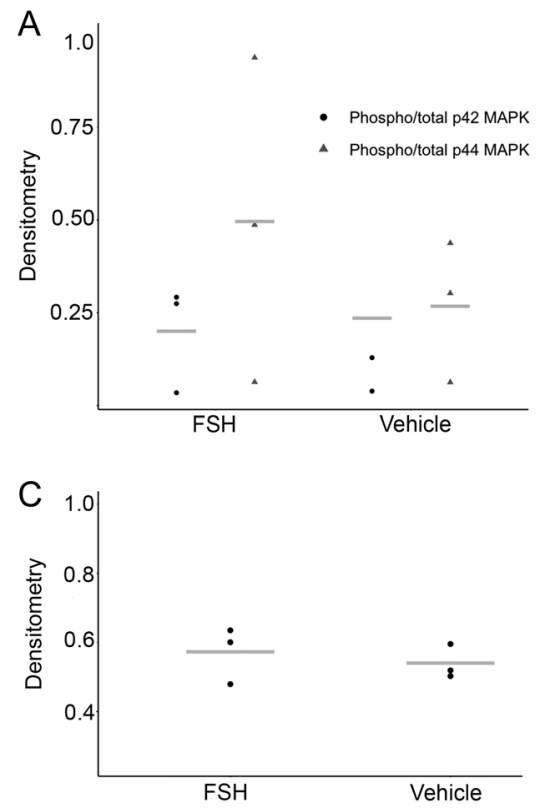

Figure 6

Expression of total and phosphorylated p42/44 MAPK and total aromatase in bovine ovarian cortical tissue exposed to FSH or vehicle for 4 days. (A) Ratio of phosphorylated:total p42/44 MAPK in FSH- (100 ng/mL) and vehicle-treated tissue. (B) Representative Western blot with histone 3A loading control. (C) Quantification of Western blot band density for total aromatase expression in ovarian cortical tissue treated with FSH. (D) Representative Western blot with histone 3A loading control.

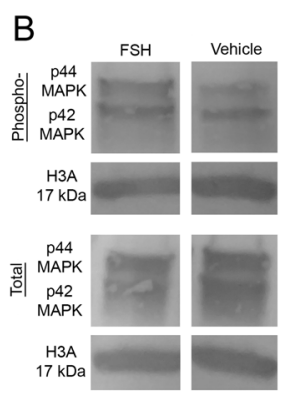

$\mathrm{D}$

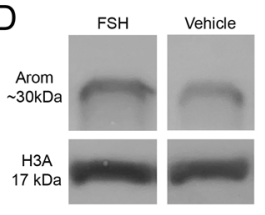


inhibitors reduced steroid secretion dramatically, even in the presence of FSH and LH (Glister et al. 2012). Expression of HSD17B1 and CYP19A1, the genes encoding the steroidogenic enzymes $17 \beta$-dehydrogenase and aromatase, respectively, was suppressed by HDAC inhibitors in the presence of FSH (Glister et al. 2012). The reduction of HDACs expression by FSH observed here could be explained as a possible mechanism of the cell context-dependent role of FSH in regulating folliculogenesis, involving suppression of steroidogenic activity and stimulation of cell proliferation in preantral follicles. In this context, the suppressed expression of HDACs could be responsible for the lack of increase in aromatase expression observed in response to FSH. Supporting this hypothesis, it has been demonstrated that HDAC11 directly inactivates Cdc25A, a Cdk/cyclin complex phosphatase that promotes progression of the cell cycle (Lozada et al. 2016). Clearly, specific experiments are required to confirm whether the regulation of transcription of $H D A C$ s by FSH in the ovarian cortex is involved in modulation of folliculogenesis.

In conclusion, we demonstrate the presence of the FSHR in preantral follicles from the primary stage onwards, and moreover, that these follicles respond to FSH stimulation. Our findings on individual, freshly isolated follicles support the conclusion that expression of the FSH receptor may be more abundant in preantral follicles of the primary stage. In the ovarian cortex containing only preantral follicles, FSH upregulates genes important for energy metabolism and MAPK signaling which may relate to proliferative effects of FSH in preantral follicles. More research is required to dissect whether the effects observed in the present study result from direct activation of FSHR. Based on our findings, we propose that FSH plays a regulatory role in early preantral folliculogenesis.

\section{Supplementary materials}

This is linked to the online version of the paper at https://doi.org/10.1530/ JOE-20-0126.

\section{Declaration of interest}

The authors declare that there is no conflict of interest that could be perceived as prejudicing the impartiality of the research reported.

\section{Funding}

This work was partially supported by USDA Multistate Project W-3112 and by the Henry A. Jastro Shields Graduate Research Award to J C (UC Davis).

\section{Acknowledgements}

The authors are thankful to Amanda Morton and Bethany Weldon for assistance with measurements and imaging processing software. RNA sequencing was carried out at the DNA Technologies and Expression Analysis Core at UC Davis, supported by NIH Shared Instrumentation Grant 1S100D010786-01.

\section{References}

Abel MH, Wootton AN, Wilkins V, Huhtaniemi I, Knight PG \& Charlton HM 2000 The effect of a null mutation in the folliclestimulating hormone receptor gene on mouse reproduction. Endocrinology 141 1795-1803. (https://doi.org/10.1210/ endo.141.5.7456)

Adriaens I, Cortvrindt R \& Smitz J 2004 Differential FSH exposure in preantral follicle culture has marked effects on folliculogenesis and oocyte developmental competence. Human Reproduction 19 398-408. (https://doi.org/10.1093/humrep/deh074)

Aguiar FLN, Lunardi FO, Lima LF, Rocha RMP, Bruno JB, MagalhãesPadilha DM, Cibin FWS, Nunes-Pinheiro DCS, Gastal MO, Rodrigues APR, et al. 2016 FSH supplementation to culture medium is beneficial for activation and survival of preantral follicles enclosed in equine ovarian tissue. Theriogenology 85 1106-1112. (https://doi. org/10.1016/j.theriogenology.2015.11.022)

Balla A, Danilovich N, Yang Y \& Sairam MR 2003 Dynamics of ovarian development in the FORKO immature mouse: structural and functional implications for ovarian reserve. Biology of Reproduction 69 1281-1293. (https://doi.org/10.1095/biolreprod.103.015552)

Bizarro-Silva C, Santos MM, Gerez JR, Gonzalez SM, Lisboa LA \& Seneda MM 2018 Influence of follicle-stimulating hormone concentrations on the integrity and development of bovine follicles cultured in vitro. Zygote 26 417-423. (https://doi.org/10.1017/ S0967199418000497)

Bolger AM, Lohse M \& Usadel B 2014 Trimmomatic: a flexible trimmer for Illumina sequence data. Bioinformatics 30 2114-2120. (https://doi. org/10.1093/bioinformatics/btu170)

Candelaria JI \& Denicol AC 2020 Characterization of isolated bovine preantral follicles based on morphology, diameter and cell number. Zygote 28 154-159. (https://doi.org/10.1017/S0967199419000832)

Chen WY, Weng JH, Huang CC \& Chung BC 2007 Histone deacetylase inhibitors reduce steroidogenesis through SCF-mediated ubiquitination and degradation of steroidogenic factor 1 (NR5A1). Molecular and Cellular Biology 27 7284-7290. (https://doi.org/10.1128/ MCB.00476-07)

Cortvrindt R, Smitz J \& Van Steirteghem AC 1997 Assessment of the need for follicle stimulating hormone in early preantral mouse follicle culture in vitro. Human Reproduction 12 759-768. (https://doi. org/10.1093/humrep/12.4.759)

de Hoon MJL, Imoto S, Nolan J \& Miyano S 2004 Open source clustering software. Bioinformatics 20 1453-1454. (https://doi.org/10.1093/ bioinformatics/bth078)

Dufour J, Cahill LP \& Mauleon P 1979 Short- and long-term effects of hypophysectomy and unilateral ovariectomy on ovarian follicular populations in sheep. Journal of Reproduction and Fertility $\mathbf{5 7}$ 301-309. (https://doi.org/10.1530/jrf.0.0570301)

Durlej M, Knapczyk-Stwora K, Duda M, Galas J \& Slomczynska M 2011 The expression of FSH receptor (FSHR) in the neonatal porcine ovary and its regulation by flutamide. Reproduction in Domestic Animals 46 377-384. (https://doi.org/10.1111/j.1439-0531.2010.01673.x)

Glister C, Satchell L, Michael AE, Bicknell AB \& Knight PG 2012 The antiepileptic drug valproic acid (VPA) inhibits steroidogenesis in bovine theca and granulosa cells in vitro. PLoS ONE 7 e49553. (https://doi. org/10.1371/journal.pone.0049553) https://joe.bioscientifica.com

https://doi.org/10.1530/JOE-20-0126 (c) 2020 Society for Endocrinology Published by Bioscientifica Ltd.
Printed in Great Britain 
Hardy K, Fenwick M, Mora J, Laird M, Thomson K \& Franks S 2017 Onset and heterogeneity of responsiveness to FSH in mouse preantral follicles in culture. Endocrinology 158 134-147. (https://doi. org/10.1210/en.2016-1435)

Hunzicker-Dunn ME, Lopez-Biladeau B, Law NC, Fiedler SE, Carr DW \& Maizels ET 2012 PKA and GAB2 play central roles in the FSH signaling pathway to PI3K and AKT in ovarian granulosa cells. PNAS 109 E2979-E2988. (https://doi.org/10.1073/pnas.1205661109)

Kristensen SG, Ebbesen P \& Andersen CY 2015 Transcriptional profiling of five isolated size-matched stages of human preantral follicles. Molecular and Cellular Endocrinology 401 189-201. (https://doi. org/10.1016/j.mce.2014.12.012)

Kumar TR, Wang Y, Lu NF \& Matzuk MM 1997 Follicle stimulating hormone is required for ovarian follicle maturation but not male fertility. Nature Genetics 15 201-204. (https://doi.org/10.1038/ng0297201)

Kwintkiewicz J, Cai Z \& Stocco C 2007 Follicle-stimulating hormoneinduced activation of Gata4 contributes in the up-regulation of Cyp19 expression in rat granulosa cells. Molecular Endocrinology 21 933-947. (https://doi.org/10.1210/me.2006-0446)

Lan RX, Liu F, He ZB, Chen C, Liu SJ, Shi Y, Liu YL, Yoshimura Y \& Zhang M 2014 Immunolocalization of GnRHRI, gonadotropin receptors, PGR, and PGRMCI during follicular development in the rabbit ovary. Theriogenology 81 1139-1147. (https://doi.org/10.1016/j. theriogenology.2014.01.043)

Law NC, Donaubauer EM, Zeleznik AJ \& Hunzicker-Dunn M 2017 How protein kinase A activates canonical tyrosine kinase signaling pathways to promote granulosa cell differentiation. Endocrinology $\mathbf{1 5 8}$ 2043-2051. (https://doi.org/10.1210/en.2017-00163)

Leggett RM, Ramirez-Gonzalez RH, Clavijo BJ, Waite D \& Davey RP 2013 Sequencing quality assessment tools to enable data-driven informatics for high throughput genomics. Frontiers in Genetics 4 288. (https://doi. org/10.3389/fgene.2013.00288)

Liao Y, Smyth GK \& Shi W 2013 The subread aligner: fast, accurate and scalable read mapping by seed-and-vote. Nucleic Acids Research $\mathbf{4 1}$ e108. (https://doi.org/10.1093/nar/gkt214)

Lozada EM, Andrysik Z, Yin M, Redilla N, Rice K \& Stambrook PJ 2016 Acetylation and deacetylation of Cdc25A constitutes a novel mechanism for modulating Cdc25A functions with implications for cancer. Oncotarget 7 20425-20439 (https://doi.org/10.18632/ oncotarget.7966)

Malcuit C, Trask MC, Santiago L, Beaudoin E, Tremblay KD \& Mager J 2009 Identification of novel oocyte and granulosa cell markers. Gene Expression Patterns 9 404-410. (https://doi.org/10.1016/J. GEP.2009.06.004)

Mao J, Wu G, Smith MF, McCauley TC, Cantley TC, Prather RS, Didion BA \& Day BN 2002 Effects of culture medium, serum type, and various concentrations of follicle-stimulating hormone on porcine preantral follicular development and antrum formation in vitro. Biology of Reproduction 67 1197-1203. (https://doi.org/10.1095/ biolreprod67.4.1197)

Marelli BE, Leiva CJM, Flores Brun RB, Ramirez CS, Failla JI, Matiller V, Amweg AN, Rey F \& Ortega HH 2018 Production and validation of a polyclonal serum against bovine FSH receptor. Reproductive Biology 18 432-439. (https://doi.org/10.1016/j.repbio.2018.09.001)

McCarthy DJ, Chen Y \& Smyth GK 2012 Differential expression analysis of multifactor RNA-Seq experiments with respect to biological variation. Nucleic Acids Research 40 4288-4297. (https://doi. org/10.1093/nar/gks042)

McGee EA, Perlas E, LaPolt PS, Tsafriri A \& Hsueh AJ 1997 Folliclestimulating hormone enhances the development of preantral follicles in juvenile rats. Biology of Reproduction 57 990-998. (https://doi. org/10.1095/biolreprod57.5.990)

Nueda MJ, Tarazona S \& Conesa A 2014 Next maSigPro: updating maSigPro bioconductor package for RNA-seq time series.
Bioinformatics 30 2598-2602. (https://doi.org/10.1093/bioinformatics/ btu333)

O'Shaughnessy PJ, Dudley K \& Rajapaksha WR 1996 Expression of follicle stimulating hormone-receptor mRNA during gonadal development. Molecular and Cellular Endocrinology 125 169-175. (https://doi. org/10.1016/S0303-7207(96)03957-3)

Oktay K, Briggs D \& Gosden RG 1997 Ontogeny of follicle-stimulating hormone receptor gene expression in isolated human ovarian follicles. Journal of Clinical Endocrinology and Metabolism $\mathbf{8 2}$ 3748-3751. (https://doi.org/10.1210/jcem.82.11.4346)

Pakarainen T, Zhang FP, Nurmi L, Poutanen M \& Huhtaniemi I 2005 Knockout of luteinizing hormone receptor abolishes the effects of follicle-stimulating hormone on preovulatory maturation and ovulation of mouse graafian follicles. Molecular Endocrinology 19 2591-2602. (https://doi.org/10.1210/me.2005-0075)

Puri P, Little-Ihrig L, Chandran U, Law NC, Hunzicker-Dunn M \& Zeleznik AJ 2016 Protein kinase A: a master kinase of granulosa cell differentiation. Scientific Reports 6 28132. (https://doi.org/10.1038/srep28132)

Rajapaksha WR, Robertson L \& O'Shaughnessy PJ 1996 Expression of follicle-stimulating hormone-receptor mRNA alternate transcripts in bovine granulosa cells during luteinization in vivo and in vitro. Molecular and Cellular Endocrinology 120 25-30. (https://doi. org/10.1016/0303-7207(96)03816-6)

Robinson MD, McCarthy DJ \& Smyth GK 2010 edgeR: a Bioconductor package for differential expression analysis of digital gene expression data. Bioinformatics 26 139-140. (https://doi.org/10.1093/ bioinformatics/btp616)

Roy SK \& Treacy BJ 1993 Isolation and long-term culture of human preantral follicles. Fertility and Sterility 59 783-790. (https://doi org/10.1016/S0015-0282(16)55860-9)

Saldanha AJ 2004 Java TreeView - extensible visualization of microarray data. Bioinformatics 20 3246-3248. (https://doi.org/10.1093/ bioinformatics/bth349)

Scarlet D, Walter I, Hlavaty J \& Aurich C 2016 Expression and immunolocalisation of follicle-stimulating hormone receptors in gonads of newborn and adult female horses. Reproduction, Fertility, and Development 28 1340-1348. (https://doi.org/10.1071/RD14392)

Schuermann Y, Rovani MT, Gasperin B, Ferreira R, Ferst J, Madogwe E, Goncalves PB, Bordignon V \& Duggavathi R 2018 ERK1/2-dependent gene expression in the bovine ovulating follicle. Scientific Reports $\mathbf{8}$ 16170. (https://doi.org/10.1038/s41598-018-34015-4)

Shiota M, Sugai N, Tamura M, Yamaguchi R, Fukushima N, Miyano T \& Miyazaki H 2003 Correlation of mitogen-activated protein kinase activities with cell survival and apoptosis in porcine granulosa cells. Zoological Science 20 193-201. (https://doi.org/10.2108/zsj.20.193)

Su S, Law CW, Ah-Cann C, Asselin-Labat ML, Blewitt ME \& Ritchie ME 2017 Glimma: interactive graphics for gene expression analysis. Bioinformatics 33 2050-2052. (https://doi.org/10.1093/bioinformatics/btx094)

Tisdall DJ, Watanabe K, Hudson NL, Smith P \& McNatty KP 1995 FSH receptor gene expression during ovarian follicle development in sheep. Journal of Molecular Endocrinology 15 273-281. (https://doi. org/10.1677/jme.0.0150273)

Verdin E, Dequiedt F \& Kasler HG 2003 Class II histone deacetylases: versatile regulators. Trends in Genetics 19 286-293. (https://doi. org/10.1016/S0168-9525(03)00073-8)

Wang XN \& Greenwald GS 1993 Hypophysectomy of the cyclic mouse. I. Effects on folliculogenesis, oocyte growth, and folliclestimulating hormone and human chorionic gonadotropin receptors. Biology of Reproduction 48 585-594. (https://doi.org/10.1095/ biolreprod48.3.585)

Wayne CM, Fan HY, Cheng X \& Richards JS 2007 Follicle-stimulating hormone induces multiple signaling cascades: evidence that activation of Rous sarcoma oncogene, RAS, and the epidermal growth factor receptor are critical for granulosa cell differentiation. Molecular Endocrinology 21 1940-1957. (https://doi.org/10.1210/me.2007-0020) https://joe.bioscientifica.com https://doi.org/10.1530/JOE-20-0126 (c) 2020 Society for Endocrinology Published by Bioscientifica Ltd. Printed in Great Britain 
Wright CS, Hovatta O, Margara R, Trew G, Winston RM, Franks S \& Hardy K 1999 Effects of follicle-stimulating hormone and serum substitution on the in-vitro growth of human ovarian follicles. Human Reproduction $\mathbf{1 4}$ 1555-1562. (https://doi.org/10.1093/humrep/14.6.1555)

Wu J, Xu B \& Wang W 2007 Effects of luteinizing hormone and follicle stimulating hormone on the developmental competence of porcine preantral follicle oocytes grown in vitro. Journal of Assisted Reproduction and Genetics 24 419-424. (https://doi.org/10.1007/s10815-007-9154-5)

Xia J, Gill EE \& Hancock RE 2015 NetworkAnalyst for statistical, visual and network-based meta-analysis of gene expression data. Nature Protocols 10 823-844. (https://doi.org/10.1038/nprot.2015.052)
Yu FQ, Han CS, Yang W, Jin X, Hu ZY \& Liu YX 2005 Role of ERK1/2 in FSH induced PCNA expression and steroidogenesis in granulosa cells. Frontiers in Bioscience 10 896-904. (https://doi. org/10.2741/1584)

Zhang W \& Liu HT 2002 MAPK signal pathways in the regulation of cell proliferation in mammalian cells. Cell Research 12 9-18. (https://doi. org/10.1038/sj.cr.7290105)

Zhang C, Wang X, Wang Z, Niu W, Zhu B \& Xia G 2013 Effect of different culture systems and 3,5,3'-triiodothyronine/follicle-stimulating hormone on preantral follicle development in mice. PLOS ONE $\mathbf{8}$ e61947. (https://doi.org/10.1371/journal.pone.0061947)

Received in final form 5 August 2020

Accepted 14 August 2020

Accepted Manuscript published online 17 August 2020 (c) 2020 Society for Endocrinology Published by Bioscientifica Ltd. Printed in Great Britain 